\title{
Fragmented Knowledge and Missing Connections between Knowledge from Different Hierarchical Organisational Levels of Reproduction among Adolescents and Young Adults
}

ANDREJ ŠORGO ${ }^{\star 1}$ AND REBEKA ŠILING ${ }^{2}$

$\approx$ Based on the responses of our sample $(\mathrm{N}=310)$ of adolescents and young adults from Slovenia (students of secondary and tertiary schools, university students) to a number of tasks covering reproduction, from the molecular to organismal levels, it can be concluded that their knowledge is seriously flawed. Correlations of knowledge between individual tasks are low, or even negative, showing patchiness and missed connections between different aspects of reproduction. Our study confirms the well-known difficulties in building a consistent body of knowledge on the genetic-inheritance axis while expanding it to the anatomy and physiology of reproduction. It is crucial to stress the quality of elementary school biology, and science (biology) courses in secondary schools because, for most people, this will be the last formal contact with some important topics that could influence their life decisions.

Keywords: knowledge; biology; misconceptions; genetics; reproduction

$1 \quad$ Corresponding Author. University of Maribor, Faculty of Natural Sciences and Mathematics and Faculty of Electrical Engineering and Computer Science, Slovenia; andrej.sorgo@um.si.

2 University of Maribor, Faculty of Natural Sciences and Mathematics, Slovenia. 
Nepovezanost in manjkajoče povezave med znanjem $\mathrm{z}$ različnih hierarhičnih organizacijskih ravni razmnoževanja, ki ga izkazujejo mladostniki in mlajši odrasli

ANDREJ Šorgo IN REBEKA ŠILING

$\approx$ Na osnovi odgovorov 310 mladostnikov in mlajših odraslih (dijakov slovenskih srednjih šol, študentov višjih in visokih šol ter univerz) na večje število nalog, povezanih $\mathrm{z}$ razmnoževanjem, na ravneh od molekularne do organizemske, lahko ugotovimo, da je njihovo znanje samo pomanjkljivo. Korelacije znanja, izkazanega $\mathrm{z}$ odgovori na posamezne naloge, so nizke in včasih celo negativne. Vzorec znanja zaznamuje nepovezanost in manjkajoče povezave med različnimi vidiki razmnoževanja. Z rezultati študije potrjujemo dobro poznane težave $\mathrm{v}$ gradnji konsistentnega korpusa znanja na osi genetika - dedovanje ter jo širimo na področji anatomije in fiziologije. Na osnovi pridobljenih spoznanj bi morali nujno pretresti kakovost poučevanja biologije $\mathrm{v}$ osnovni šoli in naravoslovja (biologije) v srednjih šolah. Za veliko večino bo namreč takrat pridobljeno znanje zadnji formalni stik s pomembnimi vsebinami, ki lahko zaznamujejo življenjske odločitve.

Ključne besede: znanje, biologija, napačni koncepti, genetika, razmnoževanje 


\section{Introduction}

Teaching about reproduction is not only one of the traditional biological topics and vital for understanding life phenomena but, especially in the case of human reproduction and sexuality, an important personal and societal issue. Reproduction of organisms and genetics, as underlying principles, are complex issues, which generate the formation of many naïve presentations, alternative concepts or misconceptions, well described by a body of research (Children's ideas, 1992; Nguyen \& Rosengren, 2004; Prokop \& Fančovičová, 2008; Yip, 1998). Particularly important are misconceptions about human reproduction because these cannot be regarded as merely a biological issue, but also as a cultural and social (societal) issue (Flowers-Coulson, Kushner \& Bankowski, 20oo; Hamani, Sciaki-Tamir, Deri-Hasid, Miller-Pogrund, Milwidsky \& Haimov-Kochman, 2007; Wynn, Foster \& Trussell, 2009).

It is possible to identify many causes behind flawed biological knowledge about reproduction and its underlying principles. One of the major reasons is the natural complexity of the issue. Reproduction exists in different forms, from asexual to sexual, and in different combinations of both; it occurs at different hierarchical organisational levels, from subcellular to organismal; inside an individual and between individuals; moreover, as a research topic it is distributed among a number of biological disciplines (De Meeûs, Prugnolle \& Agnew, 2007; Folsell \& Roughgarden, 2010; Obeso, 2004; Pineda-Krch \& Lehtilä, 2004; Tuomi \& Vuorisalo, 1989). Not adding to the simplicity is the generation of new knowledge, resulting not only in the addition of details or clarifications to the existing body of knowledge, but also in the generation of new interpretations and concepts (Haque, Gottesman \& Wong, 2009; Visscher, Hill \& Wray, 2008). Emerging knowledge often challenges both scientific explanations and naïve presentations at all hierarchic levels of reproduction and between them (e.g. Engel Clough \& Wood-Robinson, 1985; Mintzes, Trowbridge, Arnaudin \& Wandersee, 1991).

The second important cause involves misconceptions presented in study resources (textbooks) used at various educational levels (Aivelo \& Uitto, 2015; Castéra, Bruguière \& Clément, 2008; Choi \& Cho, 1987; Clément \& Castéra, 2014; Dos Santos, Joaquim \& El-Hani, 2012) and the knowledge and misconceptions held by teachers (Kurt \& Ekici, 2013; Veiga, Teixeira, Martins \& MeliçoSilvestre, 2006). After didactic transposition (Bosch \& Gascón, 2006), teaching resources often present simplified (if not erroneous) diagrams and explanations (Martins, 2010). Furthermore, they do not present a coherent overview of an issue but instead offer a number of contextually varied concepts of the same 
artefact or process, sometimes even within the same textbook (Gericke, Hagberg, dos Santos, Joaquim \& El-Hani, 2014).

Information obtained from popular commercial textbooks (Smolkin \& Donovan, 2015; Schussler, 2008) and other traditional and electronic media and informal sources, such as family, peers, and the common knowledge of a community (Merchant, Brown, Cecil, Grimley \& Oh, 2000), probably constitutes the most important source of misconceptions, especially if these are not challenged by formal education.

\section{Aims and purpose of the research}

Because reproduction can be regarded as a network of multiple processes rather than a single process occurring at different organisational levels, the aim of the study was to verify the recognition of knowledge levels and the ability to transfer knowledge from one organizational level to another by adolescents and young adults. Through the results of our research, our wish was to identify major flaws in the understanding of reproduction and the misconceptions held by adolescents and young adults at a range of different organizational levels (subcellular, cell, organismal) of reproduction. Our research was exploratory, and no intervention was provided to influence the knowledge and attitudes of the participants, who were secondary and tertiary level students.

\section{Methods}

\section{Research design}

The research design employs a mixed methodology. After the analysis of elementary and secondary school syllabi and textbooks, a contextual framework about reproduction was assembled. Based on this framework, an initial version of the test was assembled, driven by our wish to assess knowledge both as widely as possible and at different cognitive levels. Consequently, different question formats were used. The initial version was given to a number of university students and university staff for validation. After checking the comments received, an improved version was prepared. Assessment, coding and statistical procedures are presented later in this section and in the results section.

\section{Sample and sampling}

The research sample consisted of 315 participants out of 550 persons who received the questionnaire in paper and pencil form. After the exclusion of five questionnaires, 310 (56.4\%) completed questionnaires remained. The 
questionnaires were administered in the 2010/11 academic year to a number of students from the Universities of Maribor and Ljubljana, as well as general and vocational upper secondary schools. A high number of volunteers (235) failed to return their questionnaire, many of them with the explanation that it was too hard to complete and that they did not want to display their lack of knowledge. Anonymity was guaranteed, and no benefits or penalties were offered to those who participated or rejected participation. The sample characteristics are presented in Table 1.

Table 1. Sample characteristics $(N=310)$

\begin{tabular}{lcc}
\hline Demographic characteristics & Frequency & $\%$ \\
\hline Gender & 137 & 44.2 \\
Male & 173 & 55.8 \\
Female & & \\
\hline School type & 77 & 24.8 \\
Professional or vocational secondary school & 113 & 36.5 \\
General upper secondary school (gimnazija) & 190 & 73 \\
Secondary school total & 13 & 4.2 \\
Higher school & 107 & 34.5 \\
University & 120 & 38.7 \\
Tertiary schools total & $\mathrm{N}=120$ & 38.7 \\
\hline One of the elective Matura subjects was Biology & 34 & 28.3 \\
Yes & 86 & 71.7 \\
No & 116 & 37.4 \\
\hline School Grade* in Biology at the end of secondary education & $\mathrm{N}=116$ & 37.4 \\
Sufficient (2) & 5 & 1.6 \\
Good (3) & 39 & 12.6 \\
Very good (4) & 46 & 14.8 \\
Excellent (5) & 26 & 8.4 \\
\hline Total & 516 \\
\hline In Slovenian school systems, grades can be understoodas follow & & \\
\hline
\end{tabular}

*In Slovenian school systems, grades can be understood as follows: (1) insufficient; (2) sufficient; (3) good; (4) very good; and (5) excellent.

\section{Structure of the questionnaire}

Reproduction is a complex and varied issue, so our intention was to construct a manageable test dealing with the facts, processes and concepts at different hierarchical organisational levels. Our guiding principle was that the tasks should be doable based on the knowledge acquired by completing compulsory 
science and biology curricula in primary and secondary school. Based on these premises, questions and tasks were formed, covering the basic principles of reproduction, with the addition of the demographic part of the questionnaire.

At the broadest levels of knowledge (De Jong \& Ferguson-Hessler, 1996), the first content level was the subcellular, with the inclusion of structures and processes such as genes, chromosomes, gene expression, etc. The second was the cellular level, which included processes such as cell division; the third level was anatomical, and the fourth organismal. Overarching concepts (e.g. reproduction, cloning) were also included.

Because of the complexity of the material, varied assessment formats were used, as follows:

a) Open-ended questions were used, when our interest was in recognition of understanding, and to discover alternative concepts.

b) Two-tier diagnostic tests (Lin, 2004; Tsui \& Treagust, 2010); the first part offered answers of 'yes', 'no', and 'do not know'. In the second explanatory part, students were asked to explain their decision in open-ended format.

c) Naming of objects and processes in provided sketches of mitotic cell division and a dicot pistil, followed by a number of open-ended explanations.

d) Free-hand drawing (Dikmenli, 2010; Reiss et al., 2002; Sesli \& Kara, 2012) of male and female reproductive organs inside a provided outline of the male and female torso, with the additional task of naming the structures.

e) In seeking misconceptions, we provided a number of statements based on previously known misconceptions, with a 'yes', 'no', and 'do not know' response format.

Differing grading schemes were used for knowledge assessment, a feature that can be recognized in the tables in the results section.

Where students were to provide open-ended answers, they received 2 points for correct or almost completely correct answers. As correct answers, we also acknowledge answers that followed textbook explanations, even though it is known that textbook explanations are sometimes oversimplified, if not completely wrong, according to recent knowledge. One point was assigned to a partially correct answer and zero points to an incorrect or missing answer. However, in the tables, incorrect and missing answers are distinguished, because not knowing something is not equal to 'knowing' it incorrectly; however, they were graded with zero points in both cases. 


\section{Statistical procedures}

Because our interest did not lie in the construction of a new instrument, the basic unit of interpretation comprises individual items (questions, tasks) and not scales. Therefore, reliability statistics, such as Cronbach's alpha are not provided. Because occasional not-normal distribution, frequencies, median, and mode are provided in addition to means and standard deviations as measures of central tendencies. Spearman's rho was the preferred choice for calculating correlations between ordinal data, and chi-square statistics was the chosen option for calculating differences. Because practically all the differences between different educational levels and types of schools are statistically significant, they are not reported in the text. In contrast, differences between males and females are more diverse. However, knowledge of such differences can be interesting, but is of little practical value for the improvement of schoolwork, or informal education that takes place in the general public realm, because designing courses based on gender differences is an unacceptable practice in the authors' institutions.

\section{Results and comments}

\section{Concept of reproduction and basic concepts of genetics}

Open-ended tasks (Table 2) were provided to check the knowledge levels about the concept of reproduction and the basic genetics necessary to understand heredity.

Table 2. Results of responses to open-ended tasks dealing with reproduction and genetics

\begin{tabular}{|c|c|c|c|c|c|c|}
\hline & \multirow{2}{*}{ Tasks } & \multirow{2}{*}{$\begin{array}{l}\mathbf{N} \\
\%\end{array}$} & \multirow{2}{*}{$\begin{array}{l}\text { Missing } \\
\%\end{array}$} & \multicolumn{3}{|c|}{ Marks } \\
\hline & & & & 2 & 1 & 0 \\
\hline 1 & Provide a brief definition of reproduction. & $\begin{array}{l}277 \\
89.4\end{array}$ & $\begin{array}{c}33 \\
10.6\end{array}$ & $\begin{array}{c}71 \\
22.9\end{array}$ & $\begin{array}{c}95 \\
30.6\end{array}$ & $\begin{array}{c}111 \\
35.8\end{array}$ \\
\hline 2 & $\begin{array}{l}\text { Explain the difference between sexual and asexual } \\
\text { reproduction at the level of organisms. }\end{array}$ & $\begin{array}{l}258 \\
83.2\end{array}$ & $\begin{array}{c}52 \\
16.8\end{array}$ & $\begin{array}{l}25 \\
6.1\end{array}$ & $\begin{array}{l}165 \\
53.2\end{array}$ & $\begin{array}{c}68 \\
21.9\end{array}$ \\
\hline 3 & $\begin{array}{l}\text { Explain sexual reproduction with the inclusion of } \\
\text { meiotic division. }\end{array}$ & $\begin{array}{c}141 \\
45.5\end{array}$ & $\begin{array}{c}169 \\
54,4\end{array}$ & $\begin{array}{l}17 \\
5.5\end{array}$ & $\begin{array}{c}67 \\
21.6\end{array}$ & $\begin{array}{c}57 \\
18.4\end{array}$ \\
\hline 4 & $\begin{array}{l}\text { Your neighbour planted a beautiful willow tree; } \\
\text { however, you cannot find a retailer anywhere to } \\
\text { buy one. Explain how you can reproduce it with- } \\
\text { out seriously harming the mother tree. }\end{array}$ & $\begin{array}{l}196 \\
63.2\end{array}$ & $\begin{array}{c}114 \\
36.8\end{array}$ & $\begin{array}{c}135 \\
43.5\end{array}$ & $\begin{array}{c}42 \\
13.5\end{array}$ & $\begin{array}{l}19 \\
6.1\end{array}$ \\
\hline 5 & $\begin{array}{l}\text { Farmers buy hybrid maize seeds every year, even } \\
\text { if they can save part of their own grain crop to } \\
\text { be sown next year. Explain the main reason(s) for } \\
\text { their decision. }\end{array}$ & $\begin{array}{c}156 \\
50.3\end{array}$ & $\begin{array}{c}154 \\
49.7\end{array}$ & $\begin{array}{c}21 \\
6.8\end{array}$ & $\begin{array}{c}12 \\
3.9\end{array}$ & $\begin{array}{c}121 \\
39.0\end{array}$ \\
\hline
\end{tabular}




\begin{tabular}{|c|c|c|c|c|c|c|}
\hline & \multirow{2}{*}{ Tasks } & \multirow{2}{*}{$\begin{array}{l}\mathrm{N} \\
\%\end{array}$} & \multirow{2}{*}{$\begin{array}{c}\text { Missing } \\
\%\end{array}$} & \multicolumn{3}{|c|}{ Marks } \\
\hline & & & & 2 & 1 & 0 \\
\hline 6 & Provide your definition of genes. & $\begin{array}{l}221 \\
71.3\end{array}$ & $\begin{array}{c}89 \\
29.7\end{array}$ & $\begin{array}{c}61 \\
19.7\end{array}$ & $\begin{array}{l}102 \\
32.9\end{array}$ & $\begin{array}{c}58 \\
18.7\end{array}$ \\
\hline 7 & $\begin{array}{l}\text { Explain the relation between genes, chromo- } \\
\text { somes, and DNA. }\end{array}$ & $\begin{array}{l}200 \\
64.5\end{array}$ & $\begin{array}{c}110 \\
35.5\end{array}$ & $\begin{array}{c}68 \\
21.9\end{array}$ & $\begin{array}{c}46 \\
14.8\end{array}$ & $\begin{array}{c}86 \\
27.7\end{array}$ \\
\hline
\end{tabular}

One important aspect of the information presented in Table 2 is the missing answers. While almost $90 \%$ of students provide their definition of reproduction, the inclusion of meiotic division in the task resulted in the dropping out of more than half $(54.4 \%)$ of the respondents. If we add those who refused to answer the whole questionnaire, arguing that it was too difficult, to the numbers, the quality of knowledge about reproduction, as held by adolescents and young adults, can be seriously questioned. We can gain better insight via analysis of individual tasks.

The first task (1) asked students to provide their first association with the word 'reproduction'. From a range of answers (raw data not provided), it was possible to conclude that their prevailing associations were directly and indirectly connected to humans. The most frequent category $(116 ; 37.4 \%)$ of answers named sexuality, specifically human sexuality. The second category (83; $26.7 \%$ ) consisted of answers around the concept of new life, and in the third category $(58 ; 18.7 \%)$, there are answers concerning the biological concepts of species and population. Below the $10 \%$ level was the fourth category $(18 ; 5.6 \%)$, grouping answers at the cellular and sub-cellular levels; and in the fifth category (8; 2.5\%), non-human organisms are mentioned. The remaining answers are presented by a single response, with a great diversity. The most frequently identified misconception was that reproduction is the fusion of male and female sex cells, or a human instinct. From the frequencies of answers, it was possible to recognize that reproduction as a biological phenomenon is not recognized by most respondents as a universal quality of all organisms, but is seen as confined to human beings, thus confusing biological function with social ones (Meston \& Buss, 2007).

In Task 2, when asked to explain the difference between sexual and asexual reproduction, only 25 (8.1\%) explained the difference by explicitly mentioning the recombination of genetic material. Most of them (53\%) provided, under particular circumstances, partially correct answers: e.g. that two individuals are necessary for sexual reproduction. The most frequent incorrect answer was that asexual reproduction of plants is pollination. One surprising discovery was that $51(16.5 \%)$ respondents believe that artificial fertilization in humans constitutes asexual reproduction. 
Meiotic division (Task 3 ) is a basic process in the formation of haploid cells (gametes and spores) from diploid ones. Knowledge about the connection between meiotic division and asexual reproduction (e.g. spore formation) was excluded from the expected answer by the inclusion of the word 'sexual' in the statement of the task. Even if meiotic division is a key process assuring diversity, only a minority connected meiotic division with the formation of haploid cells, or the formation of gametes. Another confirmed misconception was that meiotic division appears after copulation of gametes: a mistake that might somehow be rooted in the teaching of metagenesis in plants.

The understanding of vegetative reproduction (cloning) as a type of asexual reproduction at the level of organisms was addressed by Task 4 . The surprise is the relatively large number of them $(36.8 \%)$ who did not even attempt to give an answer about the common, everyday practice of vegetative plant reproduction, showing that school science is disconnected from everyday experience. This results in correspondents answering incorrectly the statement 'Cloning is an exclusively artificial process' (Table 7), showing that many students do not recognize cloning as a process that occurs naturally, and they connect it to artificial practices. However, among those who did provide answers, the number $(57 \%)$ who answered correctly or partially correctly answered greatly outnumbered those $(6.1 \%)$ who provided incorrect answers.

Task 5 was the greatest challenge for students, and only a minority provided correct answers, showing that school science is disconnected from an understanding of everyday practices, such as gardening or animal breeding.

Without understanding the basic concept of a gene (Task 6), it is difficult to understand heredity. As correct answers, even though not consistent with current definitions (Gerstein et al., 2007; Smith \& Adkison, 2010), were acknowledged statements such as that a gene is a basic material unit or carrier of heredity; and at the molecular level, that a gene is part of a DNA molecule at a definite position on the chromosome, etc. Partially correct answers mostly comprise mentioning only a particular gene function, such as coding of protein, while omitting aspects like regulatory functions or synthesis of ribosome RNA. One prevailing misconception was that a gene is a double helix containing all information about an individual, showing genetic determinism (Castéra \& Clément, 2014).

Marked as correct and partially correct answers (36.7\%) about the relation between genes, chromosomes, and DNA (Task 7) were those where the mention of (one) correct relation was provided, e.g. that chromosomes contain DNA, and that genes are situated on chromosomes, etc. A common mistake was to change the order, e.g. to say that the gene contains the chromosome. 
More than one third of respondents did not answer, thus indicating flawed knowledge.

Table 3. Correlations (Spearman's rho) between responses to the tasks provided in Table 2). Correlations were calculated for those, who answered all tasks $(N=98)$

$\begin{array}{lrrrrr} & \text { Task 2 } & & & & \\ \text { Task 3 } & .304^{* *} & \text { Task 3 } & & & \\ \text { Task 6 } & .135 & .196 & \text { Task 6 } & & \\ \text { Task 7 } & .181 & .250^{*} & .217^{*} & \text { Task 7 } & \\ \text { Task 4 } & -.192 & .105 & -.065 & .138 & \text { Task 4 } \\ \text { Task 5 } & .054 & -.081 & -.114 & .012 & -.070 \\ \text { ** Correlation is significant at the 0.01 level (2-tailed). } & \\ * & \text { Correlation is significant at the 0.05 level (2-tailed). }\end{array}$

From Table 3, it can be seen that the correlations (Spearman's rho) between the answers to the tasks presented in Table 2 are low or even negative. In the matrix were included only those who answered all items $(\mathrm{N}=98)$. We can interpret the results as showing that knowledge at one level is not necessarily transferred to other levels and that knowledge is fragmented and unconnected to a coherent network. Weak positive correlations show in some cases that only a minority of the students are able to link knowledge from different levels into a coherent whole. Moreover, two tasks ( 4 and 5) correlate negatively with other tasks. Common to both these tasks is that they are somehow practical, and connected with a real-life understanding of the world, marking the separation between school science and 'real life', everyday practices.

\section{Knowledge and understanding of mitotic division}

Mitotic division is one of the cornerstones in understanding reproduction in eukaryotes and the comprehension of contemporary topics such as cloning. A figure showing the basic phases of mitotic division (five stages) as presented in a number of textbooks was used as backup information for three tasks (Table 4). Simplified inner structures (nucleus, cytoplasm, mitotic spindle and chromosomes) were shown in the figure. The first task was graded on a scale of two, one, zero, and the latter two on a scale of correct (1) and incorrect (o). 
Table 4. Results of answers concerning knowledge and understanding of mitotic division

\begin{tabular}{|c|c|c|c|c|c|c|}
\hline & \multirow{2}{*}{ Tasks } & \multirow{2}{*}{$\begin{array}{l}\mathrm{N} \\
\%\end{array}$} & \multirow{2}{*}{$\begin{array}{l}\text { Missing } \\
\%\end{array}$} & \multicolumn{3}{|c|}{ Marks } \\
\hline & & & & 2 & 1 & 0 \\
\hline 1 & $\begin{array}{l}\text { Provide the name of the cell division in the } \\
\text { diagram. }\end{array}$ & $\begin{array}{l}193 \\
62.3\end{array}$ & $\begin{array}{l}117 \\
37.7\end{array}$ & $\begin{array}{c}7 \\
2.3\end{array}$ & $\begin{array}{c}113 \\
36.5\end{array}$ & $\begin{array}{c}73 \\
23.5\end{array}$ \\
\hline 2 & Sort the cells into the correct order. & $\begin{array}{l}178 \\
57.4\end{array}$ & $\begin{array}{c}132 \\
42.6\end{array}$ & $*$ & $\begin{array}{c}88 \\
28.4\end{array}$ & $\begin{array}{c}90 \\
29.0\end{array}$ \\
\hline 3 & Name the marked structure in the diagram. & $\begin{array}{c}175 \\
56.5\end{array}$ & $\begin{array}{c}135 \\
43.5\end{array}$ & * & $\begin{array}{l}143 \\
46.1\end{array}$ & $\begin{array}{c}32 \\
10.3\end{array}$ \\
\hline
\end{tabular}

Note: * two points were not provided

Many missing answers (about 40\%) is a common pattern in all three tasks, showing that mitotic cell division was poorly learned and forgotten by a large number of respondents. The correct answer (mitotic division) was given by only seven persons, with the majority answering 'mitosis', which is the correct answer for the division of a nucleus. The source of this partially correct answer is most probably the loose use of the term in teaching. The most frequent misconception was recognition of the process as meiosis. The correct order of the phases, even though taught in elementary school and repeated in most secondary school programmes, was provided by less than one-third of the students. Less than half the students correctly recognize the structure (chromatid); chromosome, chromatid and DNA were counted as correct answers. The high number of missing answers shows a lack of confidence in answering. Because of the diverse response formats, correlations between items were not calculated. However, we can show, by combining other answers from Tables 2 and 7 that there is a missing link between genetics (the relation between genes, chromosomes and DNA; plants and bacteria do not contain DNA), and mitotic cell division and structures involved in it. Additionally, there is indirect evidence of a gap between the recognition of the meaning of the phrase 'identical division' used in common explanations of mitotic division, and cloning, which was perceived by the majority to be an 'exclusively artificial process' (Table 7).

\section{Knowledge about the anatomy of the reproductive organs}

Knowledge at the anatomical level was verified using three tasks. In the first task, they had to identify a structure (a pistil in longitudinal section, with a visible embryonal sack) presented as a sketch. About two-third of respondents (201, 66.1\%) provided answers, and of these $132(42.6 \%)$ correctly identified the object as a pistil (carpel). The rest $(73,23.5 \%)$ incorrectly identified the structure 
as an anther. When asked to explain the function of the structure, correct or partially correct answers connected to plant reproduction (reproduction; pollination; fertilization) were provided by 139 (44.8\%) of respondents; there were 136 (43.9\%) missing responses and 35 incorrect answers (e.g. insemination). We can connect these incorrect and missing answers to the misconception that 'Plants reproduce only asexually' (see Table 7).

The anatomy of human reproductive organs was assessed using two tasks. We provided blank outlines of two human torsos in the frontal position, and correspondents were instructed to sketch and name the male and female reproductive organs, using the outlines.

Table 5. Results for knowledge of female reproductive organ anatomy

\begin{tabular}{|c|c|c|c|c|c|c|c|c|c|c|c|c|}
\hline \multirow{2}{*}{ Organ } & \multirow{2}{*}{$\begin{array}{l}\mathbf{N} \\
\%\end{array}$} & \multirow{2}{*}{$\begin{array}{c}\text { Missing } \\
\%\end{array}$} & \multicolumn{10}{|c|}{ Codes* } \\
\hline & & & 1 & 2 & 3 & 4 & 5 & 6 & 7 & 8 & 9 & 10 \\
\hline \multirow{2}{*}{ Vagina } & 200 & 110 & 124 & 4 & 48 & 9 & & & 1 & 11 & 2 & 1 \\
\hline & 64.5 & 35.5 & 40.0 & 1.3 & 15.5 & 2.9 & & & 0.3 & 3.5 & 0.6 & 0.3 \\
\hline \multirow{2}{*}{ Ovaries } & 151 & 159 & 66 & 55 & 7 & 15 & 2 & & & 3 & 1 & 2 \\
\hline & 48.7 & 51.3 & 21.3 & 17.1 & 2.3 & 4.8 & 0.6 & & & 1.0 & 0.3 & 0.6 \\
\hline \multirow{2}{*}{ Fallopian tube } & 122 & 188 & 49 & 43 & 10 & 14 & 2 & 1 & & & 1 & 2 \\
\hline & 39.4 & 60.6 & 15.8 & 13.9 & 3,2 & 4.5 & 0.6 & 0.3 & & & 0.3 & 0.6 \\
\hline \multirow{2}{*}{ Body of uterus } & 119 & 191 & 68 & 33 & 6 & 6 & 1 & & & & 1 & 2 \\
\hline & 38.4 & 61.6 & 21.9 & 10.6 & 1.9 & 1.9 & 0.3 & & & & 0.3 & 0.6 \\
\hline \multirow{2}{*}{ Labia majora } & 37 & 273 & 22 & & 11 & 3 & & & & 1 & & \\
\hline & 11.9 & 88.1 & 7.1 & & 3.5 & 1.0 & & & & 0.3 & & \\
\hline \multirow{2}{*}{ Cervix } & 17 & 282 & 17 & 6 & 3 & & & & & & & 1 \\
\hline & 5.5 & 91.0 & 5.5 & 1.9 & 1.0 & & & & & & & 0.3 \\
\hline \multirow{2}{*}{ Labia minora } & 14 & 296 & 12 & & 1 & & & & & 1 & & \\
\hline & 4.4 & 95.5 & 3.8 & & 0.3 & & & & & 0.3 & & \\
\hline \multirow{2}{*}{ Clitoris } & 8 & 302 & 6 & & 1 & & & & & 1 & & \\
\hline & 1.9 & 97.4 & 1.9 & & 0.3 & & & & & 0.3 & & \\
\hline $\begin{array}{l}\text { Greater vestibular } \\
\text { glands }\end{array}$ & & $\begin{array}{c}310 \\
100,0\end{array}$ & & & & & & & & & & \\
\hline
\end{tabular}

Note: Codes* (0: missing; 1: correct sketch, correct label, in the correct position; 2: correct sketch, correct label, in an incorrect position; 3: correct sketch, missing label, in the correct position; 4: correct sketch, missing label, at incorrect position; 5: correct sketch, incorrect label, at correct position; 6: correct sketch, incorrect label, in the incorrect position; 7: anatomically incorrect sketch, correct label; 8: missing sketch, organ labelled in the correct position; 9: missing sketch, incorrect position, labelled; 10: organ named by only a word (listing). 
Table 6. Results for knowledge of male reproductive organ anatomy

\begin{tabular}{|c|c|c|c|c|c|c|c|c|c|c|c|c|}
\hline \multirow{2}{*}{ Organ } & \multirow{2}{*}{$\begin{array}{l}\mathrm{N} \\
\%\end{array}$} & \multirow{2}{*}{$\begin{array}{c}\text { Missing } \\
\%\end{array}$} & \multicolumn{10}{|c|}{ Codes* } \\
\hline & & & 1 & 2 & 3 & 4 & 5 & 6 & 7 & 8 & 9 & 10 \\
\hline \multirow{2}{*}{ Penis } & 231 & 79 & 131 & 18 & 57 & 9 & 1 & 1 & & 4 & 8 & 2 \\
\hline & 74.5 & 25.5 & 42.3 & 5.8 & 18.4 & 2.9 & 0.3 & 0.3 & & 1.3 & 2.6 & 0.6 \\
\hline \multirow{2}{*}{ Testicles } & 227 & 83 & 65 & 69 & 26 & 59 & & 1 & 1 & 3 & 1 & 2 \\
\hline & 73.2 & 26.8 & 21.0 & 22.3 & 8,4 & 19.0 & & 0.3 & 0.3 & 1.0 & 0.3 & 0.6 \\
\hline \multirow{2}{*}{ Scrotum } & 11 & 299 & 6 & 1 & 3 & 1 & & & & & & \\
\hline & 3.5 & 96.5 & 1.9 & 0.3 & 1.0 & 0.3 & & & & & & \\
\hline \multirow{2}{*}{ Vas deferens } & 43 & 267 & 22 & 16 & 1 & & & & 3 & & & 1 \\
\hline & 13.9 & 86.1 & 7.1 & 5.2 & 0.3 & & & & 1.0 & & & 0.3 \\
\hline \multirow{2}{*}{ Prostate } & 33 & 277 & 13 & 14 & & & & & 3 & & 1 & 2 \\
\hline & 10.6 & 89.4 & 4.2 & 4.5 & & & & & 1.0 & & 0.3 & 0.6 \\
\hline \multirow{2}{*}{ Epididymis } & 13 & 297 & 12 & 1 & & & & & & & & \\
\hline & 4.2 & 95.8 & 3.9 & 0.3 & & & & & & & & \\
\hline \multirow{2}{*}{ Seminal vesicles } & 9 & 301 & 4 & 3 & & 1 & & 1 & & & & \\
\hline & 2.9 & 97.1 & 1.3 & 1.0 & & 0.3 & & 0.3 & & & & \\
\hline \multirow{2}{*}{ Urethra } & 8 & 302 & 6 & 2 & & & & & & & & \\
\hline & 2.6 & 97.4 & 1.9 & 0.6 & & & & & & & & \\
\hline \multirow{2}{*}{ Bulbourethral gland } & & 310 & & & & & & & & & & \\
\hline & & 100 & & & & & & & & & & \\
\hline
\end{tabular}

Note: For coding, see Table 5.

Both tables (Table 5, Table 6) reveal a large number of missing values. About a quarter of students failed to attempt these tasks. Their number corresponded with missing values for the penis and the vagina. We cannot imagine that adolescents and young adults can be truly unaware of the existence of these two organs, but for some reason they did not even attempt to sketch the reproductive system. Prokop and Fančovičova (2006) recognized the same pattern; missing sketches were attributed to the complexity of the female and male reproductive systems, or to the small area provided for the sketch, and subjective norms concerning what should or should not be drawn, according to personal attitudes. From our study, we cannot reach any affirmative conclusions about the reasons for not attempting a drawing, so our conclusions are based on those who started the task. Interesting side comments from some students were that they could only draw the reproductive from the side projection, in the way commonly present in textbooks. However, by analysing the figures of those who drew at least one structure, we can conclude that knowledge of the inner anatomy of human reproductive organs is clearly shallow. A difference in the levels of knowledge about the male and female reproductive systems exists. Students exhibited far better knowledge about the female reproductive system 
and could provide details, a finding which is probably connected to topics such as pregnancy and the menstrual cycle, where knowledge about the reproductive organs is essential. The most frequently sketched and labelled structures were the ovaries, fallopian tubes, uterus and vagina, but they neglected to sketch external parts, which are not essential to an understanding of processes such as the menstrual cycle, birth control and pregnancy. Some of them sketched breasts on the female torso, possibly because of a confusion between primary and secondary sex characteristics. Sketches of the male reproductive system were in most cases reduced to the penis and testicles. Almost nobody named the scrotum, and in many cases, the testicles were positioned in the abdomen. It comes as a surprise that nobody, not even those who finished their secondary education with the Matura examination in Biology, could name the vestibular and bulbourethral glands, and only eight positioned the clitoris in the diagram, indicating that topics such as arousal and coitus are left to informal sources, while the social function of sexuality is commonly reduced to contraception and sexually transmitted diseases.

\section{Two-tier question on asexual reproduction in humans}

Understanding of the difference between sexual and asexual reproduction was tested by a two-tier question about whether humans can reproduce asexually. Only 11 (3.5\%) students failed to answer, and 15 (4.8\%) marked the 'Do not know' option, thus showing confidence in their knowledge. The affirmative 'yes' was marked by 56 (18.1\%) and 'no' was marked by 228 (73.5\%) students. In the second part, they were asked to provide an explanation of their answer; 129 (41.6\%) failed to answer, and only $43(15.9 \%)$ of students were able to answer correctly or at least partially correctly. Four students answered that identical (mitotic) division of a fertilized egg cell could be recognized as asexual, showing deeper understanding. The others connected asexual reproduction with cloning, or thought that asexual reproduction appears after sexual reproduction in the formation of identical twins. A total of 138 (44.5\%) of students provided incorrect explanations, showing deep misunderstanding of the concept of reproduction. Again, there emerges the concept that artificial fertilization is asexual reproduction; this is expressed in a number of ways using words, such as 'children from a tube'. The anecdotal answer was that asexual reproduction is 'when boys do it by themselves'.

\section{Two-tier question, about whether two sperm can fertilize an egg cell}

As in the previous question, only a minority $(13,4.2 \%)$ failed to answer or marked the 'Do not know' (21,6.8\%) option. Affirmative 'yes' was marked 
by $213(68.7 \%)$ and 'no' by $63(20.3 \%)$. However, when asked for an explanation, only $32(10.3 \%)$ provided correct or partially correct answers. Only six students correctly stated that such an incident could occur but that such a fertilized egg is aborted. As partially correct, we recognized answers in which it was explained that after fertilization by the first sperm, the egg cell activates a layer that prevents other sperm from penetrating the cell. In addition to the 111 (35.8\%) missing answers, 167 (53.9\%) were incorrect. The most common identified misconception was that this is the way twins are formed, indicating that they missed the connection between the outcomes of identical (mitotic) and meiotic (division) and processes at the chromosome (genome) levels.

Table 7. Frequency distribution of answers to a variety of statements directly and indirectly connecting reproduction, inheritance with genetics. Correct answers are in parentheses

\begin{tabular}{|c|c|c|c|c|c|}
\hline Task ID & Statement & $\begin{array}{l}\text { Missing } \\
\%\end{array}$ & $\begin{array}{c}\text { Correct } \\
\%\end{array}$ & $\begin{array}{l}\text { Incorrect } \\
\%\end{array}$ & $\begin{array}{c}\text { Do not know } \\
\%\end{array}$ \\
\hline \multirow{2}{*}{$1(1)$} & If parents have brown eyes, their child cannot & 2 & 232 & 61 & 15 \\
\hline & have blue eyes. (No) & 0.6 & 74.8 & 19.7 & 4.8 \\
\hline \multirow{2}{*}{$2(31)$} & If a rabbit and a cat have intercourse, the & 6 & 203 & 31 & 70 \\
\hline & offspring are rabbits with short ears. (No) & 1.9 & 65.5 & 10.0 & 22.6 \\
\hline \multirow{2}{*}{$3(29)$} & \multirow{2}{*}{ Plants do not contain DNA. (No) } & 6 & 185 & 74 & 45 \\
\hline & & 1.9 & 59.7 & 23.9 & 14.5 \\
\hline \multirow{2}{*}{$4(18)$} & \multirow{2}{*}{$\begin{array}{l}\text { The human embryo receives its food from } \\
\text { mother's blood system. (Yes) }\end{array}$} & 6 & 182 & 69 & 53 \\
\hline & & 1.9 & 58.7 & 22.3 & 17.1 \\
\hline \multirow{2}{*}{$5(32)$} & \multirow{2}{*}{$\begin{array}{l}\text { During sexual reproduction, the sexual organs } \\
\text { must be in contact. (No) }\end{array}$} & 4 & 169 & 116 & 21 \\
\hline & & 1.3 & 54.5 & 37.4 & 6.8 \\
\hline \multirow{2}{*}{$6(33)$} & \multirow{2}{*}{$\begin{array}{l}\text { Several males must fertilize a cat, otherwise, } \\
\text { all offspring will be of the same colour. (No) }\end{array}$} & 2 & 168 & 82 & 58 \\
\hline & & 0.6 & 54.2 & 26.5 & 18.7 \\
\hline \multirow{2}{*}{$7(25)$} & \multirow{2}{*}{ Bacteria do not contain DNA. (No) } & 6 & 162 & 80 & 62 \\
\hline & & 1.9 & 52.3 & 25.8 & 20.0 \\
\hline \multirow{2}{*}{$8(24)$} & \multirow{2}{*}{ Plants reproduce only asexually. (No) } & 1 & 161 & 114 & 34 \\
\hline & & 0.3 & 51.9 & 36.8 & 11.0 \\
\hline \multirow{2}{*}{$9(5)$} & \multirow{2}{*}{ Hypophysis influences sexual glands. (Yes) } & 7 & 159 & 24 & 120 \\
\hline & & 2.3 & 51.3 & 7.7 & 38.7 \\
\hline \multirow{2}{*}{$10(17)$} & \multirow{2}{*}{$\begin{array}{l}\text { During prenatal development, the human } \\
\text { embryo breathes with lungs. (No) }\end{array}$} & 8 & 158 & 38 & 106 \\
\hline & & 2.6 & 51.0 & 12.3 & 34.2 \\
\hline \multirow{2}{*}{$11(12)$} & \multirow{2}{*}{ Fertilization occurs in the human uterus. (No) } & 2 & 158 & 125 & 25 \\
\hline & & 0.6 & 51.0 & 40.3 & 8.1 \\
\hline \multirow{2}{*}{$12(14)$} & \multirow{2}{*}{$\begin{array}{l}\text { The male determines the sex of a human } \\
\text { new-born. (Yes) }\end{array}$} & 4 & 131 & 134 & 41 \\
\hline & & 1.3 & 42.3 & 43.2 & 13.2 \\
\hline \multirow{2}{*}{$13(6)$} & \multirow{2}{*}{$\begin{array}{l}\text { Hermaphroditism means the same as asexual } \\
\text { reproduction. (No) }\end{array}$} & 7 & 123 & 23 & 157 \\
\hline & & 2.3 & 39.7 & 7.4 & 50.6 \\
\hline \multirow{2}{*}{$14(23)$} & \multirow{2}{*}{$\begin{array}{l}\text { By using a brush, someone can pollinate solely } \\
\text { anemophilous (wind-borne) plants. (No) }\end{array}$} & 7 & 105 & 82 & 116 \\
\hline & & 2.3 & 33.9 & 26.5 & 37.4 \\
\hline
\end{tabular}




\begin{tabular}{|c|c|c|c|c|c|}
\hline Task ID & Statement & $\begin{array}{l}\text { Missing } \\
\quad \%\end{array}$ & $\begin{array}{c}\text { Correct } \\
\%\end{array}$ & $\begin{array}{l}\text { Incorrect } \\
\%\end{array}$ & $\begin{array}{c}\text { Do not know } \\
\%\end{array}$ \\
\hline $15(28)$ & $\begin{array}{l}\text { A newt is an intermediate stage in the } \\
\text { development of frogs. (No) }\end{array}$ & $\begin{array}{c}5 \\
1.6\end{array}$ & $\begin{array}{c}101 \\
32.6\end{array}$ & $\begin{array}{c}126 \\
40.6\end{array}$ & $\begin{array}{c}78 \\
25.2\end{array}$ \\
\hline $16(20)$ & $\begin{array}{l}\text { The umbilical cord is connected to the } \\
\text { mother's small intestine, which supplies food } \\
\text { to the embryo. (No) }\end{array}$ & $\begin{array}{c}5 \\
1.6\end{array}$ & $\begin{array}{c}90 \\
29.0\end{array}$ & $\begin{array}{l}148 \\
47.7\end{array}$ & $\begin{array}{c}67 \\
21.6\end{array}$ \\
\hline $17(7)$ & $\begin{array}{l}\text { Some organisms can develop from unfertilized } \\
\text { eggs. (Yes) }\end{array}$ & $\begin{array}{c}8 \\
2.6\end{array}$ & $\begin{array}{c}86 \\
27.7\end{array}$ & $\begin{array}{c}145 \\
46.5\end{array}$ & $\begin{array}{c}71 \\
22.9\end{array}$ \\
\hline $18(10)$ & Cloning is an exclusively artificial process. (No) & $\begin{array}{c}5 \\
1.6\end{array}$ & $\begin{array}{c}83 \\
26.8\end{array}$ & $\begin{array}{l}195 \\
62.9\end{array}$ & $\begin{array}{l}27 \\
8.7\end{array}$ \\
\hline
\end{tabular}

Note: highest values are in bold.

The statements presented in Table 7 tested a number of potential misconceptions. The difference between the results in this table and those achieved by other forms of assessment (open ended, two-tier or drawing) is the low number of missing answers. From the table, it can also be seen that respondents answered any particular answer correctly answered only in $25 \%$ to $75 \%$ of cases, and that only ten of the eighteen items were answered correctly by more than half the respondents. The best result was achieved on the item about the recessive inheritance of eye colour, and the worst on the recognition of cloning as a naturally occurring process. For some answers, we can accept that the apparent lack of knowledge is the result of uncertainty because of the terminology used or because the topic was not 'covered' by curricula. An example of such knowledge is the statement that 'Some organisms can develop from an unfertilized egg. However, the answers given to some other items clearly indicate that some students lack many basic concepts of biology, such as reproductive barriers between species, the role of DNA in an organism, and/or pregnancy. An example in point is the inability to correctly answer in the case of the statement, that 'The umbilical cord is connected to mother's small intestine from where it supplies food to embryo' revealing a deep misunderstanding of foetal development. For some answers, we can confirm, that they only confirm our knowledge revealed from our studies on genetics and biotechnology (Šorgo \& Ambrožič-Dolinšek, 2009, 2010; Šorgo, et al., 2011; Šorgo, et al., 2014), while the rest only confirm our suspicions about the poor quality of biological knowledge held by a number of students. 
Table 8. Correlations (Spearman's rho) between responses to the tasks provided in Table 7. Correlations were calculated for those who completed all tasks $(N=269)$

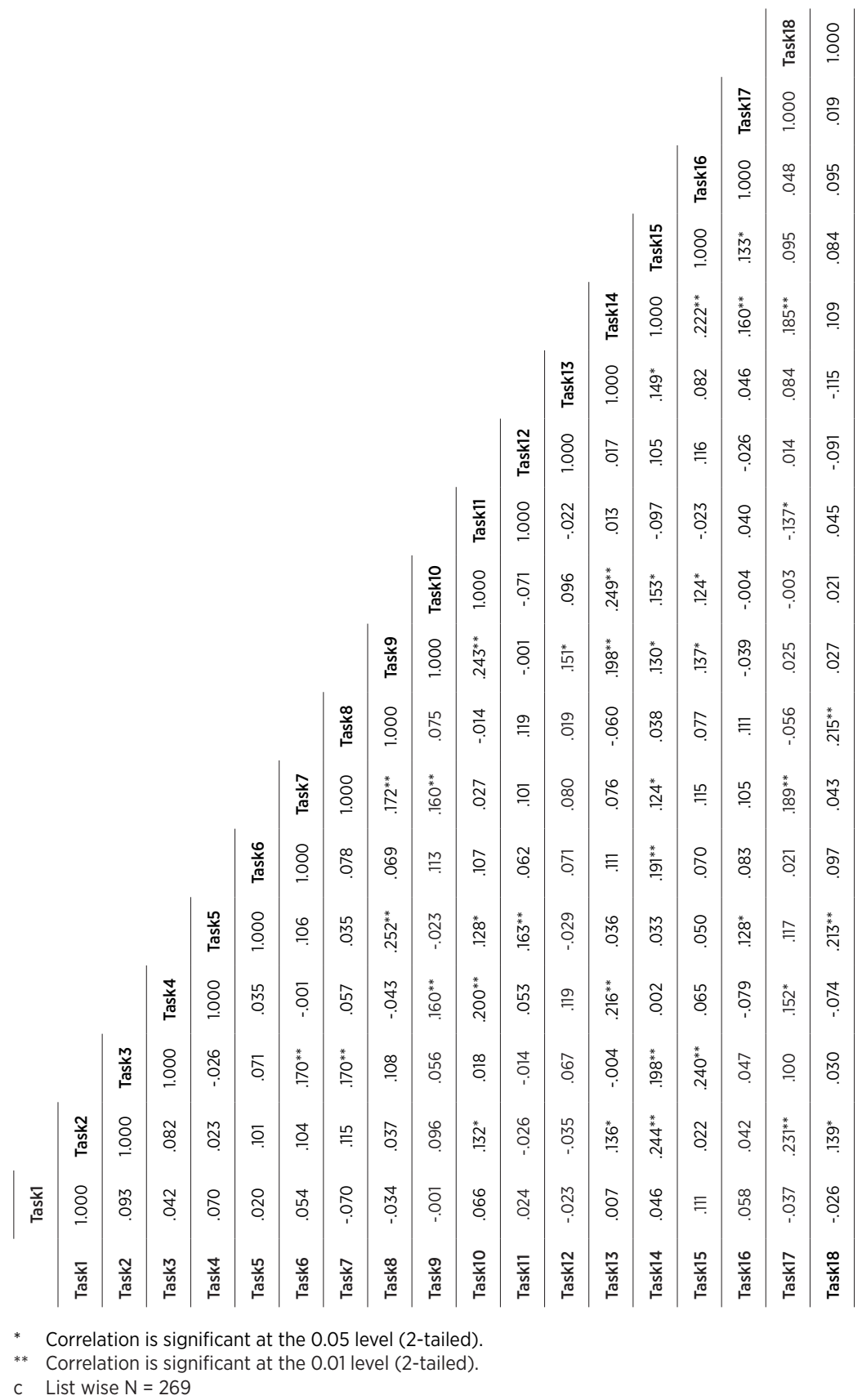


From the correlation matrix (Table 8), it is again evident that correlations between items are low, and in some cases even negative, showing that knowledge about reproduction is not being connected in a coherent network, thus confirming the results from Table 3. Moreover, when comparing two conceptually identical items, such as 'Bacteria do not contain DNA' and 'Plants do not contain DNA', it was possible to recognize that most of those who correctly answered one of the item, gave an incorrect answer to the second one in most cases. $($ Rho $=.169)$. We do not have a good explanation for this, but probably the problem lies in the patchy teaching of similar basic concepts.

\section{Conclusions}

From the responses of our sample $(\mathrm{N}=310)$ of adolescents and young adults, we gain an impression about their comprehension of reproduction, which is one of the most important biological issues. We cannot be satisfied with these findings, especially when we know that more than 200 recipients of the questionnaire refused to answer, arguing that the questions were simply too difficult for them. Among those who answered, a large number of missing, or 'do not know' responses forms a constant pattern. Because the items are largely based on textbook knowledge, missing answers can be attributed to a lack of knowledge and not to personal reasons (Prokop \& Fančovičova, 2006). Given the fact that at least 34 respondents finished their secondary education with Biology as an elective Matura examination, and that 120 respondents are students in tertiary education, the results (e.g. the inability to sketch the reproductive organs) are disturbing. Our study confirms the familiar challenge of building a consistent body of knowledge on the genetic-inheritance axis (Lewis \& Wood-Robinson, 200o), expanding it to the anatomy and physiology of reproduction. These respondents already have difficulties distinguishing between reproduction as 'The sexual or asexual process by which organisms generate new individuals of the same kind' (AHD, n. d.), and sexuality as a complex network of human behaviours, where the generation of offspring (reproduction) is a possible outcome of such activities. Connections between concepts of reproduction and basic concepts of genetics and cell division(s) are weak; respondents even have problems with the definition of a gene as a basic hereditary unit, and the relations between genes, chromosomes and DNA. At this point, we would like to underscore the quality of elementary school biology and of science (biology) courses in secondary schools, because this will be the last formal contact for most citizens with some of the important topics influencing their life decisions. 
The implications for biology teaching as a whole, not only teaching about reproduction, call for a transformation in the methods and strategies of teaching Biology (Science) from the former transmission (Šorgo et al., 2011; Šorgo \& Špernjak, 2012) to transformative practices. Teaching multidimensional issues, such as reproduction, as a biological discipline-based approach, where one issue is split into fragments and taught in a mosaic fashion at different hierarchical levels, sometimes years apart, with the faint hope that students will construct a picture from pieces by themselves, is not producing results to be proud of. As can be revealed from the present study, the formation of coherent concepts does not happen; moreover, unconnected pieces are easily lost from memory. The pattern can be recognized in the open-ended and twotier questions, where students answer the first part correctly but are incapable of providing an explanation for their decisions. The findings are parallel with the findings on the knowledge levels of Slovenian students as revealed by the PISA and TIMSS studies, which show that students are weak in comprehension (Štraus \& Markelj, 2011). Our study only indicates a problem and does not provide solutions. We can only say that recent educational strategies have not produced the expected results. From the range of strategies, plausible outcomes can be expected from an approach proposed by Knippels (2002). She proposed a strategy in which the teacher moves between different organisational levels.

\section{References}

AHD. Reproduction. (n.d.) American Heritage ${ }^{\circledast}$ Dictionary of the English Language, Fifth Edition. (2011). Retrieved 11. 6. 2016 from http://www.thefreedictionary.com/reproduction. Aivelo, T., \& Uitto, A. (2015). Genetic determinism in the Finnish upper secondary school biology textbooks. Nordic Studies in Science Education, 11(2), 139-152.

Bosch, M., \& Gascón, J. (2006). Twenty-five years of the didactic transposition. ICMI Bulletin, 58 , 51-63. Retrieved 9.3. 2017 from https://edisciplinas.usp.br/pluginfile.php/54469/mod_resource/ content/1/Texto\%2oATD/25\%20anos\%2ode\%2oATD.pdf.

Castéra, J., \& Clément, P. (2014). Teachers' conceptions about the genetic determinism of human behaviour: A survey in 23 countries. Science \& Education, 23(2), 417-443.

Castéra, J., Bruguière, C., \& Clément, P. (2008). Genetic diseases and genetic determinism models in French secondary school biology textbooks. Journal of Biological Education, 42(2), 53-59.

Children's ideas about reproduction and inheritance. National Curriculum Science Support Project, 1992. Retrieved 12. 6. 2016 from https://www.learner.org/courses/essential/life/support/pdf/4_

Reproduction.pdf.

Choi, S. I., \& Cho, H. H. (1987). An Analysis of Misconceptions about the Concepts of Cell-division, Reproduction and Fertilization in High School Biology Textbook I. Journal of the Korean Association 
for Science Education, 7(1), 1-17.

Clément, P., \& Castéra, J. (2014). Multiple representations of human genetics in biology textbooks. In D. F. Treagust \& C. Y. Tsui (Eds.), Multiple representations in biological education (pp. 147-163). Springer. Netherlands.

De Jong, T., \& Ferguson-Hessler, M. G. (1996). Types and qualities of knowledge. Educational Psychologist, 31(2), 105-113.

De Meeûs, T., Prugnolle, F., \& Agnew, P. (2007). Asexual reproduction: genetics and evolutionary aspects. Cellular and Molecular Life Sciences, 64(11), 1355-1372.

Dikmenli, M. (2010). Misconceptions of cell division held by student teachers in biology: A drawing analysis. Scientific Research and Essay, 5(2), 235-247.

Dos Santos, V. C., Joaquim, L. M., \& El-Hani, C. N. (2012). Hybrid deterministic views about genes in biology textbooks: A key problem in genetics teaching. Science \& Education, 21(4), 543-578. Engel Clough, E., \& Wood-Robinson, C. (1985). Children's understanding of inheritance. Journal of Biological Education, 19(4), 304-310.

Flowers-Coulson, P. A., Kushner, M. A., \& Bankowski, S. (2000). The information is out there, but is anyone getting it? Adolescent misconceptions about sexuality education and reproductive health and the use of the internet to get answers. Journal of Sex Education and Therapy, 25(2-3), 178-188.

Folse, H. J., \& Roughgarden, J. (2010). What is an individual organism? A multilevel selection perspective. The Quarterly Review of Biology, 85(4), 447-472.

Gericke, N. M., Hagberg, M., dos Santos, V. C., Joaquim, L. M., \& El-Hani, C. N. (2014). Conceptual variation or incoherence? Textbook discourse on genes in six countries. Science \& Education, 23(2), $381-416$.

Gerstein, M. B., Bruce, C., Rozowsky, J. S., Zheng, D., Du, J., Korbel, J. O., ... \& Snyder, M. (2007).

What is a gene, post-ENCODE? History and updated definition. Genome research, 17(6), 669-681.

Hamani, Y., Sciaki-Tamir, Y., Deri-Hasid, R., Miller-Pogrund, T., Milwidsky, A., \& Haimov-

Kochman, R. (2007). Misconceptions about oral contraception pills among adolescents and physicians. Human reproduction, 22(12), 3078-3083.

Haque, F., Gottesman, I. I., \& Wong, A. H. (2009). Not really identical: epigenetic differences in monozygotic twins and implications for twin studies in psychiatry. American Journal of Medical Genetics Part C: Seminars in Medical Genetics, 151(2), 136-141). Wiley Subscription Services, Inc., A Wiley Company.

Knippels, M. C. P. J. (2002). Coping with the abstract and complex nature of genetics in biology education: The yo-yo learning and teaching strategy (Doctoral Dissertation). University of Utrecht. Online: http://dspace.library.uu.nl/handle/1874/219.

Kurt, H., \& Ekici, G. (2013). Determining cognitive structures and alternative conceptions on the concept of reproduction (The case of pre-service biology teachers). Creative Education, 4(9), 572-587. Lewis, J., \& Wood-Robinson, C. (2000). Genes, chromosomes, cell division and inheritance-do students see any relationship? International Journal of Science Education, 22(2), 177-195.

Lin, S. W. (2004). Development and application of a two-tier diagnostic test for high school students' 
understanding of flowering plant growth and development. International Journal of Science and Mathematics Education, 2(2), 175-199.

Martins, L. A. C. P. (2010). The dissemination of the chromosome theory of Mendelian heredity by Morgan and his collaborators around 1915: a case study on the distortion of science by scientists.

Filosofia e História da Biologia, 5(2), 327-367.

Merchant, J. S., Brown, P. R., Cecil, H., Grimley, D., \& Oh, M. K. (200o,). Adolescents and sexually transmitted diseases: Lack of common knowledge and false beliefs. Journal of Investigative Medicine, 48(1), 139A-139A)

Meston, C. M., \& Buss, D. M. (2007). Why humans have sex. Archives of Sexual Behavior, 36(4), 477-507.

Mintzes, J. J., Trowbridge, J. E., Arnaudin, M. W., \& Wandersee, J. H. (1991). Children's biology: Studies on conceptual development in the life sciences. In S. Glynn, R. Yeany \& B. Britton (Eds.), The psychology of learning science (pp. 179-202). Hillsdale: Lawrence Erlbaum.

Nguyen, S. P., \& Rosengren, K. S. (2004). Parental reports of children's biological knowledge and misconceptions. International Journal of Behavioral Development, 28(5), 411-420.

Obeso, J. R. (2004). A hierarchical perspective in allocation to reproduction from whole plant to fruit and seed level. Perspectives in Plant Ecology, Evolution and Systematics, 6(4), 217-225.

Pineda-Krch, M., \& Lehtilä, K. (2004). Costs and benefits of genetic heterogeneity within organisms. Journal of Evolutionary Biology, 17(6), 1167-1177.

Prokop, P., \& Fančovičova, J. 2006. Students' ideas about the human body: do they really draw what they know? Journal of Baltic Science Education, 10(2), 86-95.

Prokop, P., \& Fančovičová, J. (2008). Students'understanding of human pregnancy. Journal of Baltic Science Education, 7(1), 37-47.

Reiss, M. J., Tunnicliffe, S. D., Andersen, A. M., Bartoszeck, A., Carvalho, G. S., Chen, S. Y., ... \& Mulemwa, J. (2002). An international study of young peoples' drawings of what is inside themselves. Journal of Biological Education, 36(2), 58-64.

Schussler, E. E. (2008). From flowers to fruits: How children's books represent plant reproduction. International Journal of Science Education, 30(12), 1677-1696.

Sesli, E., \& Kara, Y. (2012). Development and application of a two-tier multiple-choice diagnostic test for high school students' understanding of cell division and reproduction. Journal of Biological Education, 46(4), 214-225.

Smith, M. U., \& Adkison, L. R. (2010). Updating the Model Definition of the Gene in the Modern Genomic Era with Implications for Instruction. Science \& Education, 19(1), 1-20.

Smolkin, L. B., \& Donovan, C. A. (2015). Science and Literacy: Considering the Role of Texts in Early Childhood Science Education. In K. C. Trundle \& M. Sackes (Eds.), Research in Early Childhood Science Education (pp. 211-236). Springer. Netherlands.

Šorgo, A., \& Ambrožič-Dolinšek, J. (2010). Knowlege of, attitudes toward, and acceptance of genetically modified organisms among prospective teachers of biology, home economics, and grade school in Slovenia. Biochemistry and Molecular Biology Education, 38(3), 141-150. 
Šorgo, A., \& Ambrozis-Dolinsek, J. (2009). The relationship among knowledge of, attitudes toward and acceptance of genetically modified organisms (GMOs) among Slovenian teachers. Electronic Journal of Biotechnology, 12(4), 1-2.

Šorgo, A., Ambrozic-Dolinsek, J., Usak, M., \& Özel, M. (2011). Knowledge about and acceptance of genetically modified organisms among pre-service teachers: a comparative study of Turkey and Slovenia. Electronic Journal of Biotechnology, 14(4), 5 .

Šorgo, A., Usak, M., Aydogdu, M., Keles, O., \& Ambrozic-Dolinsek, J. (2011). Biology teaching in upper secondary schools: comparative study between Slovenia and Turkey. Energy education Science and Technology Part B: Social and Educational Studies, 3(3), 305-314.

Šorgo, A., Usak, M., Kubiatko, M., Fančovičova, J., Prokop, P., Puhek, M., ... \& Bahar, M. (2014). A cross-cultural study on freshmen's knowledge of genetics, evolution, and the nature of science. Journal of Baltic Science Education, 13(1), 6-18.

Šorgo, A., \& Špernjak, A. (2012). Practical work in biology, chemistry and physics at lower secondary and general upper secondary schools in Slovenia. Eurasia Journal of Mathematics, Science \& Technology Education, 8(1), 11-19.

Štraus, M., \& Markelj, N. (2011). Doseganje temeljnih in najvišjih ravni pismenosti slovenskih učenk in učencev $\mathrm{v}$ rezultatih raziskave PISA. [Attainment of Baseline and Highest Levels of Literacy Among Slovene Students According to PISA Study Results]. Sodobna Pedagogika, 62(2), 158-198. Tsui, C. Y., \& Treagust, D. (2010). Evaluating Secondary Students' Scientific Reasoning in Genetics Using a Two-Tier Diagnostic Instrument. International Journal of Science Education, 32 (8), 1073-1098.

Tuomi, J., \& Vuorisalo, T. (1989). Hierarchical selection in modular organisms. Trends in ecology ed evolution, 4(7), 209-213.

Veiga, L., Teixeira, F., Martins, I., \& Meliço-Silvestre, A. (2006). Sexuality and human reproduction: a study of scientific knowledge, behaviours and beliefs of Portuguese future elementary school teachers. Sex Education, 6(1), 17-29.

Visscher, P. M., Hill, W. G., \& Wray, N. R. (2008). Heritability in the genomics era-concepts and misconceptions. Nature Reviews Genetics, 9(4), 255-266.

Wandersee, J. H., Fisher, K. M., \& Moody, D. E. (2000). The nature of biology knowledge; Mapping biology knowledge (pp. 25-37). Norwell: Kluwer.

Wynn, L. L., Foster, A. M., \& Trussell, J. (2009). Can I get pregnant from oral sex? Sexual health misconceptions in e-mails to a reproductive health website. Contraception, 79(2), 91-97.

Yip, D. Y. (1998). Children's misconceptions on reproduction and implications for teaching. Journal of Biological Education, 33(1), 21-26. 


\section{Biographical note}

Andrej Šorgo, PhD, is an Associate Professor of Biology Didactics at the Faculty of Natural Sciences and Mathematics, and a part time researcher at the Faculty of Electrical Engineering and Computer Science, University of Maribor. He has Masters and PhD degrees in Biology from the University of Ljubljana. He has published textbooks, and research articles and presented his work at number of conferences. He has over 20 years of experience as a secondary and higher vocational school teacher. He has won an award for being 'The most innovative secondary school teacher'.

REBEKA ŠILING graduated in Educational Biology and Educational Philosophy from the Faculty of Natural Sciences and Mathematics, University of Maribor, Slovenia. She is a $\mathrm{PhD}$ candidate at the Institute for Water of the Republic of Slovenia. She has an interest in research on the ecology of aquatic ecosystems. She gained her experiences working in several research institutions (University of Otago, Slovenian Academy of Sciences and Arts in Ljubljana, etc.). 